\title{
Aerobic degradation of oil-based mud drilling fluid by in situ bacteria in the Hawizeh Marshes
}

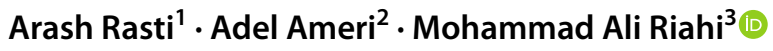

Received: 21 May 2021 / Accepted: 12 August 2021 / Published online: 26 August 2021

(c) The Author(s) 2021

\begin{abstract}
The increasing global demand for hydrocarbon has brought new challenges in the petroleum reservoir's drilling process. Non-biodegradable chemical additives are used in drilling fluid and it leads to endangering the environment and personnel safety. Thus, there is a great need for new biodegradable drilling fluid additives that can protect the environment and personal safety while drilling is done well. This study with help of microbial analysis investigates the effects of in situ bacteria to degenerate the gasoline inside the oil-based mud, in the returned lubricant from one of the oil wells next to the Hawizeh Marshes. Four types of bacteria inside the oil-based mud were observed. According to the high growth and degradation of crude oil, one strain was selected. Determination of the coagulase and clumping test shows that the isolated strain belongs to staphylococcus. We investigate the performance of the staphylococcus bacterium on the lubricant from biological degradation aspects, using a gas chromatography technique. It was observed that the exposure of a small amount of the bacteria against $10 \mathrm{~mL}$ of lubricant indicates a considerable degree of degeneration, only in a few days. The residual crude oil in the culture medium was analyzed by gas chromatography (GC) and SARA. The results confirmed that the strain can degrade crude oil and produce lighter hydrocarbon. The saturate fraction increased about 23\%, while the Resin and Asphaltene fractions decreased about $11 \%$ and $12 \%$, respectively. This research is the first report on the characterization of crude oil-degrading bacteria from in situ bacteria at Hawizeh Marsh and by using this bacterium in the field the effect of oil pollution can be reduced on this marsh environment in a few days.
\end{abstract}

Keywords Oil-based mud $\cdot$ In situ bacteria $\cdot$ Hawizeh Marshes $\cdot$ Biodegradation $\cdot$ Marsh environment

\section{Introduction}

Drilling mud with specific composition is one of the important parts of the drilling operation (Elshreef and Lashin 2016). The purpose of using drilling mud is to transfer well cuttings from the bottom of the well to the surface (Patel

Mohammad Ali Riahi

mariahi@ut.ac.ir

Arash Rasti

arash.rasti@srbiau.ac.ir

Adel Ameri

adel.ameri.ir@gmail.com

1 Department of Petroleum, Science and Research Branch, Islamic Azad University, Tehran, Iran

2 Faculty of Mechanical Engineering, Khomeinishahr Branch, Islamic Azad University, Isfahan, Iran

3 Institute of Geophysics, University of Tehran, Tehran, Iran et al. 2019). Other functions of the drilling mud are to keep the drill bit cool, underground pressure control, and wellbore stability (Elshreef and Lashin 2016). Furthermore, the type of fluid base used depends on drilling and formation needs, as well as the requirements for disposition of the fluid after it is no longer needed. Drilling muds are a special class of drilling fluids used to drill most deep wells (Johannes, 2015). For instance, water-based mud is used for limestone formation, whereas oil-based mud is used for shale formation (Alwassiti et al. 2020). Oil-based mud is more resistant to corrosion as compared to water-based mud. Although oilbased mud has some benefits due to environmental problems, the oil companies prefer to use other types of drilling mud rather than oil-based drilling mud for drilling shale formations (Folayan et al. 2017).

In developing countries, oil-based mud is used for drilling in the shale formation to prevention exchange with the water present in the formation. In contrast, if for shale formation water-based mud is used, the formation swells and causes 
wellbore damage (Shu He et al. 2016). One of the important reasons developing countries especially those which have petroleum reservoirs using oil-based mud and other petroleum products for well logging is that crude oil is cheap and abundant, as well use of oil-based mud is common in third world countries; the National Iranian Oil Company is a salient example in this case. Moreover, many of the commercially available drilling fluid additives fall under the category of non-biodegradable materials, and the higher focus on economic and performance with little or no attention to the environment had led to the use of toxic chemical additives in the formulation of conventional oil-based systems (Amanullah 2007).

In general, chemical additives that are used for oil-based mud which is mentioned above divide into three types, $\mathrm{PH}$ control, viscosity control, and filtrate control. To keep oilbased mud $\mathrm{pH}$ from 9.5 to 10.5 , we need to use caustic soda. For controlling viscosity, especially for decreasing viscosity, materials such as phosphates, tannins, legnin, and lignosulfates are used. Finally, filtrate control includes soluble and insoluble materials that will be added to the mud filtrate to affect the hydrostatic pressure. These materials are $\mathrm{CaCo} 3, \mathrm{BaSO} 4$, and $\mathrm{Fe} 2 \mathrm{O} 3$, also, sodium hydroxide, potassium chloride, potassium sulfate, polyamine, chromiumcontaining thinners, and fluid loss additives, etc. Overall, they have negative impacts on the environment (Abo Taleb et al. 2019).

According to the above description, drilling mud includes hazardous compounds which are dangerous for the environment. Environmental protection agencies (EPA) around the world have set strict environmental regulations, standards, and guidelines related to drilling consumables management. Thus, it is mandatory for the oil and gas companies to follow the trend of developing environmentally friendly drilling practices with the target of reducing the effects of generating drilling waste, which is considered as the second-largest volume of waste to the environment (Haut et al. 2007). Several techniques have been applied by the oil and gas industry to overcome the impacts of drilling waste on the environment, and an example of these techniques is using environmentally friendly drilling fluid additives except oil-based mud (Abo Taleb et al. 2019).

In this case, after the end of drilling progress, the oil and gas industry instead of eliminating the oil-based mud or recycling it, spread drilling mud into the environment, burn or mix it with the soil. Although the environment-friendly drilling fluid additives are absent in the oil-based mud, such additives can be used to eliminate them without harming the environment. However, lubricant is one of the serious problems in petroleum industries, but it seems biotechnology has an approach to keep a safe environment from oil pollutants. For instance, a similar study (Ekanem and Ogunjobi 2017) shows in situ bacteria are able to utilize lubricant.
Microbial technologies are becoming accepted worldwide as cost-effective and environmentally friendly approaches to eliminate environmental risk (Vidali 2001).

\section{Hawizeh Marshes area case study}

Evidence from one of the drilling oil companies next to Hawizeh Marshes which are located at the Iran-Iraq border (Fig. 1) shows returned lubricant mixed with cement and soda to becoming harder material and then deposited in an unknown place within the drilling area (Fig. 2). Figures 2, 3,4 , and 5 were borrowed from the drilling company next to the Hawizeh Marshes.

Moreover, wastewater gathers in the waste pool which is located exactly next to the Hawizeh Marshes which include oil (Fig. 4).

Meanwhile, Hawizeh Marshes are full of reed vegetation, while as can be seen in Fig. 5 reed vegetation is gone. According to the observations, water and soil are polluted in this area.

To date, bioremediation is the best method for the elimination of oil spills (Bayat et al. 2015). The aim of this study is to find crude oil-degrading bacteria in return oil-based mud at the Hawizeh Marshes. Also, identification of these strains and the degradation capacity of these isolates is another purpose of this research.

\section{Materials and methods}

\section{Sample collection}

Lubricant samples were collected from one of the wells in the Hawizeh Marshes field which is located near Ahwaz, southwest of Iran. Drilling fluid properties which were used for the hole by $2771 \mathrm{~m}$ depth are shown in Table 1 .

\section{Culture and identification of bacteria}

Oil-based mud samples were cultured in two growth mediums, Blood Agar and EMB (Fig. 6). Anaerobe Neomycin 5\% Sheep Blood Agar is a selective medium used in qualitative procedures for the isolation and cultivation of fastidious and slow-growing obligatory anaerobic bacteria from a variety of clinical and nonclinical specimens. Eosin Methylene Blue Agar (EMB), Levine is a slightly selective and differential plating medium for the isolation of gram-negative enteric bacteria. EMB Agar, Levine, without Lactose is provided for convenience in genetic studies of enteric bacilli (Zimbro et al. 2009).

After two days, four species included one fungus and three bacteria grew in blood agar, but no bacteria grew in EMB (Fig. 7). 


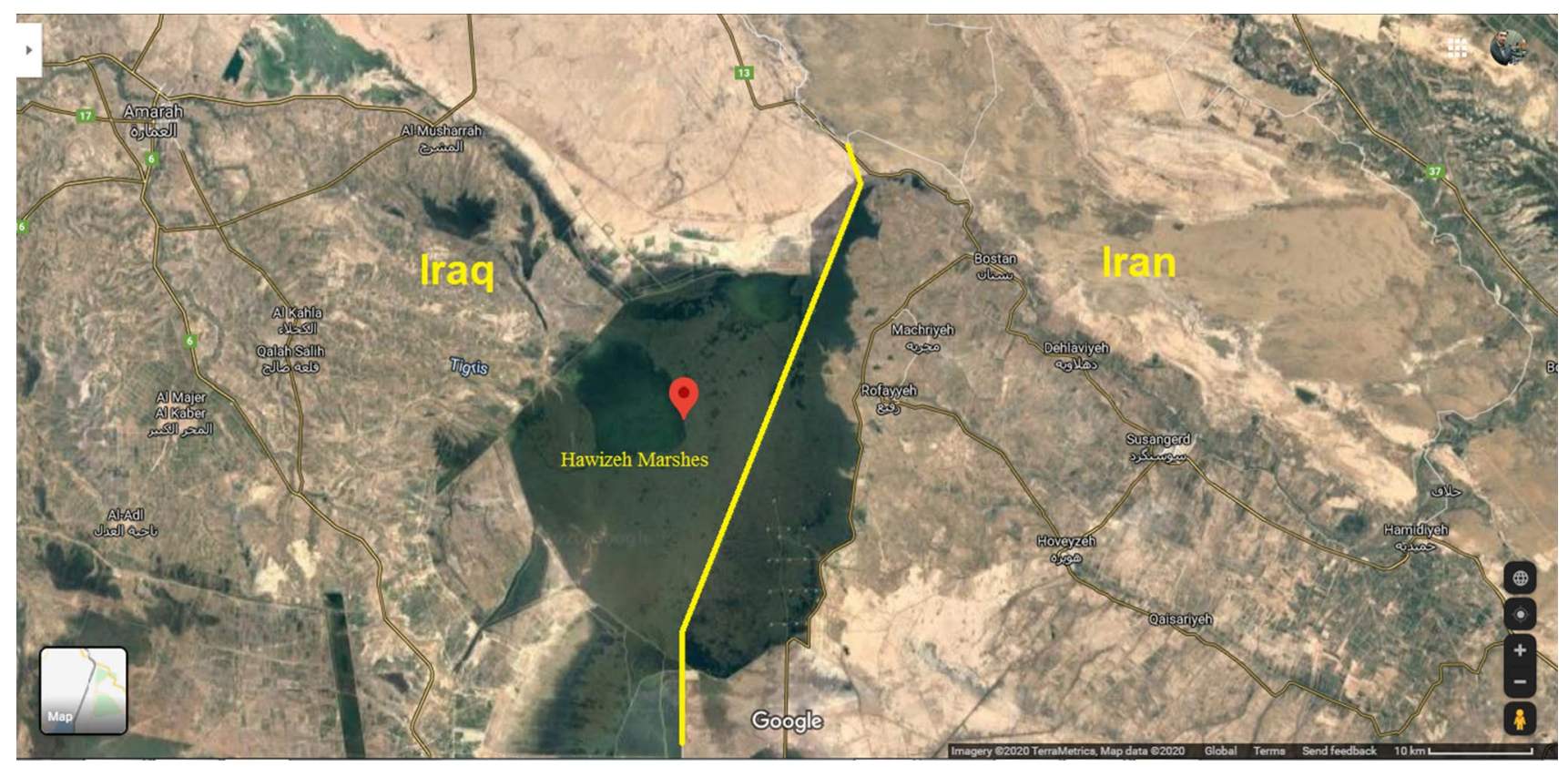

Fig. 1 Location map of the Hawizeh Marshes “31.576849, 47.746538” (Google Maps on May 25, 2020)

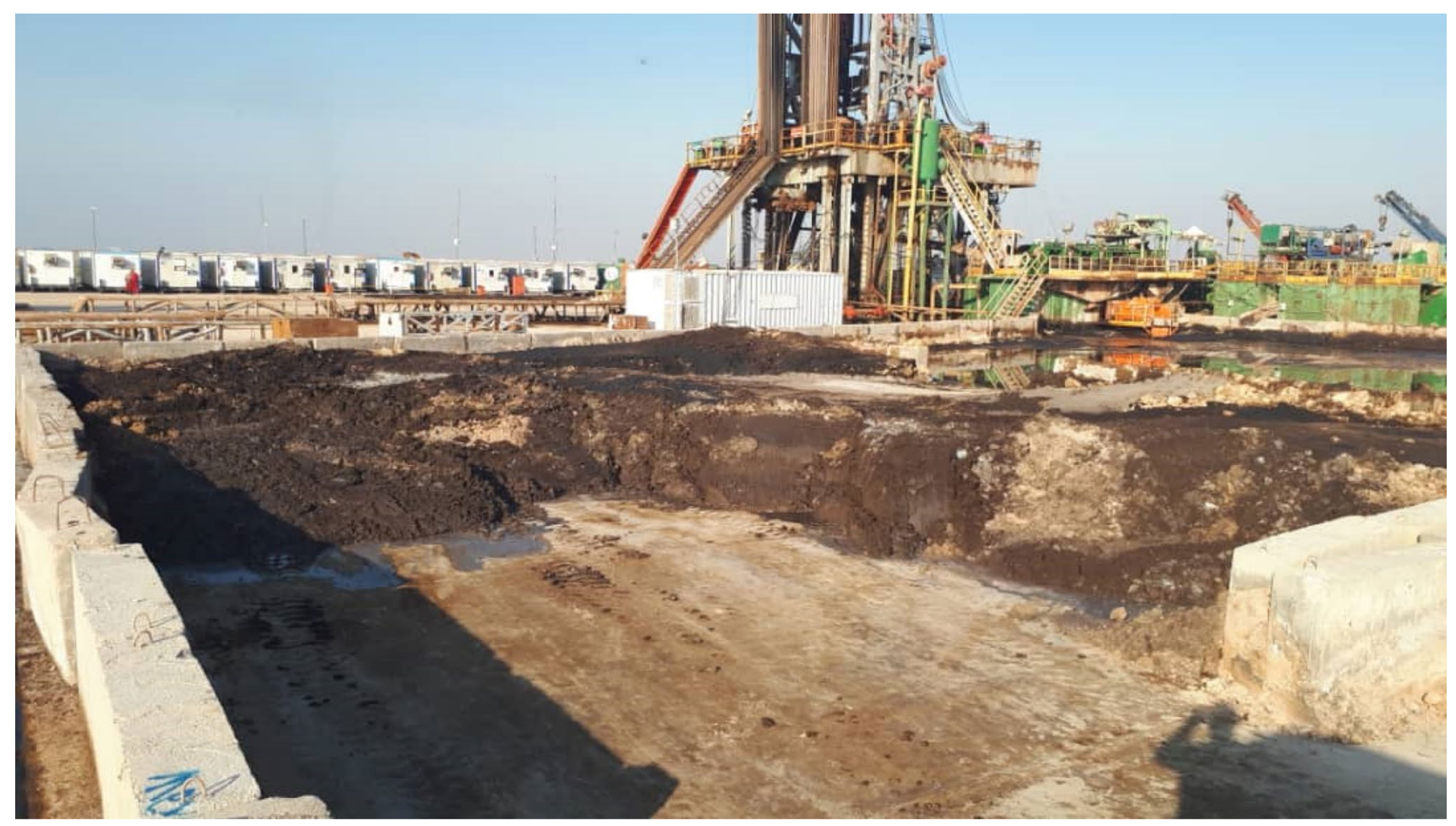

Fig. 2 Returned lubricant mixed with soil in the waste pool without having any standard cover

Three bacteria that grew in blood agar were sampled and cultured in separate blood agar for further studies (Fig. 8 Fig. 9).
According to Fig. 6, it is only bacteria No. 2 that has more growth than other species, then it was decided to investigate this bacterium on lubricant. Therefore, bacteria No. 2 


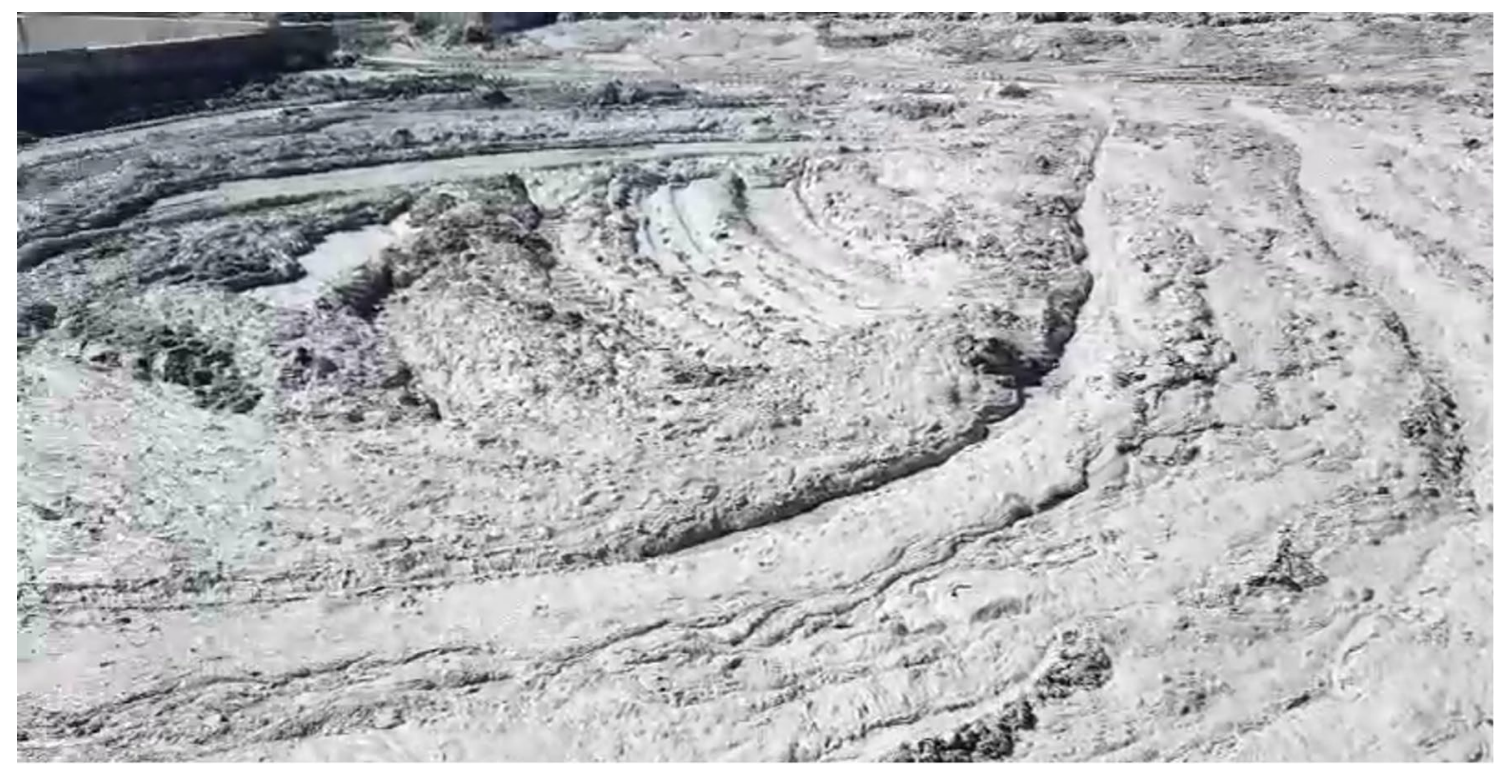

Fig. 3 Preparing returned lubricant for burial

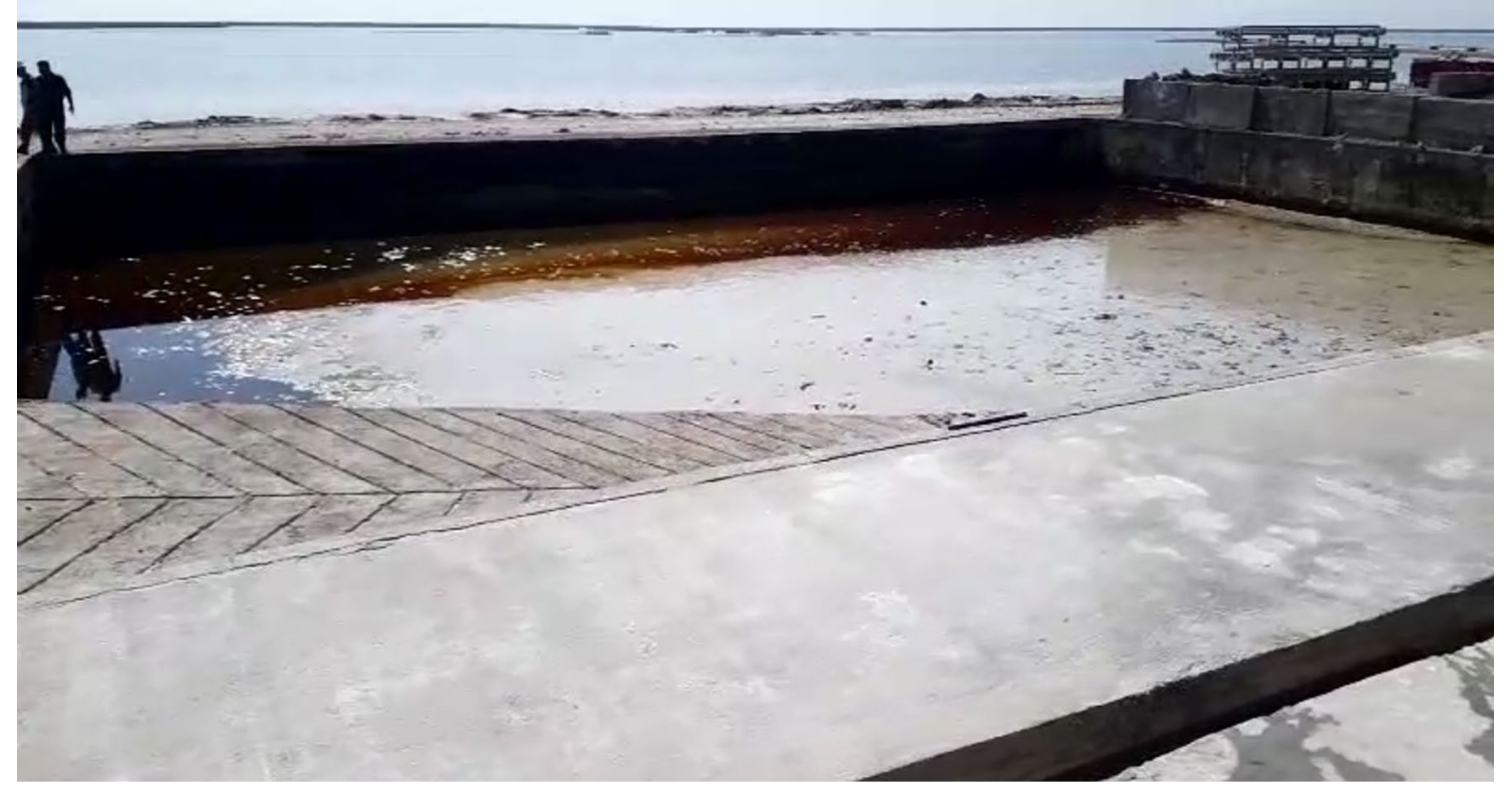

Fig. 4 Oil spills in the wastewater pool

transferred to another blood agar medium for proliferation (Fig. 10).

\section{Bacterial identification}

The coagulase and clumping tests were used to identify the species of bacteria. Staphylococcus aureus is known to produce coagulase, which can clot plasma into a gel in a tube or agglutinate cocci in the slide. This test is useful in differentiating $S$. aureus from other coagulase-negative staphylococci.
Most strains of $S$. aureus produce two types of coagulase, free coagulase, and bound coagulase. Free coagulase is an enzyme that is secreted extracellularly, and bound coagulase is referred to as a cell wall-associated protein. Free coagulase is detected in tube coagulase test, and bound coagulase is detected in slide coagulase test. Slide coagulase test may be used to screen isolates of $S$. aureus, and tube coagulase may be used for confirmation. There are seven antigenic types of free coagulase; however, only one antigenic type of bound coagulase exists. Free coagulase is heat-labile, while 


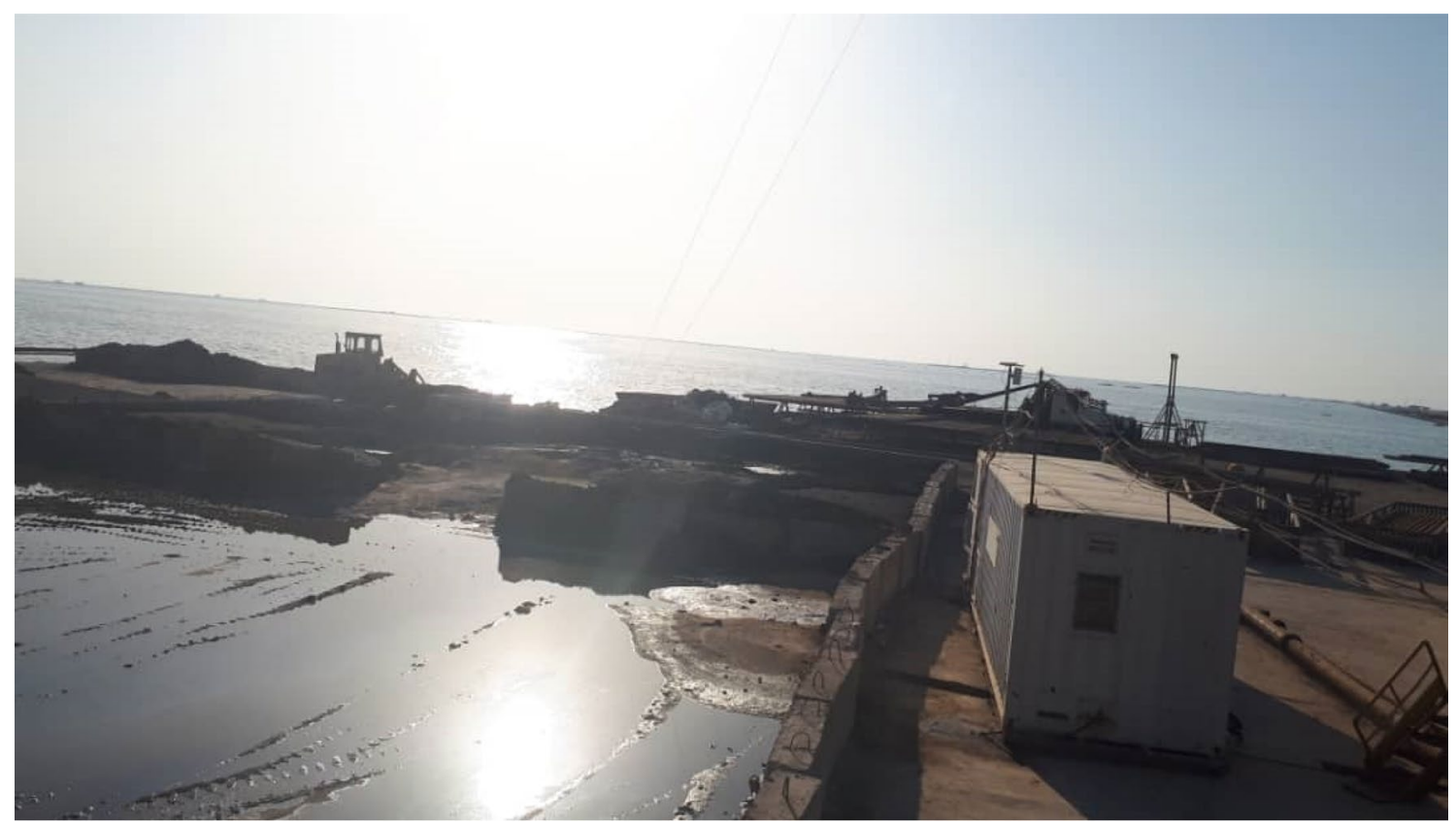

Fig. 5 Reed vegetation is gone in the drilling field next to the Hawizeh Marshes

Table 1 Lubrication properties

\begin{tabular}{ll}
\hline Chemical names & Function \\
\hline Base Oil EDC 99-DW & $\begin{array}{l}\text { Deep Water Base Oil } \\
\text { MI Emul P DW }\end{array}$ \\
MI Emul S DW & $\begin{array}{l}\text { Secondary Emulsi- } \\
\text { fier and Oil Wetting } \\
\text { agent }\end{array}$ \\
& Fluid Loss Reducer \\
MI FL DW & Viscosifier \\
MI Ovis DW & Primary Emulsifier \\
MI Emul P DW & \\
CaCL2 (salt phase) & \\
Lime & \\
Water (Brine phase) & \\
Lime stone powder & \\
\hline
\end{tabular}

bound coagulase is heat stable. According to the bacterial form in Fig. 10 and the results of coagulase-negative tests and clumping positive test, thereby, the species of bacteria were identified as Staphylococcus. Staphylococcus is a genus of Gram-positive, facultative anaerobic organisms, and form under the microscope is grape-like clusters (Gillespie and Hawkey, 2006).

\section{Gas chromatography and column chromatography performance}

A sample of oil-based mud was analyzed by SARA and GC before and after treatment to investigate the changes after adding the bacteria to the lubricant, under laboratory conditions. In the beginning, we got a sample from bacteria
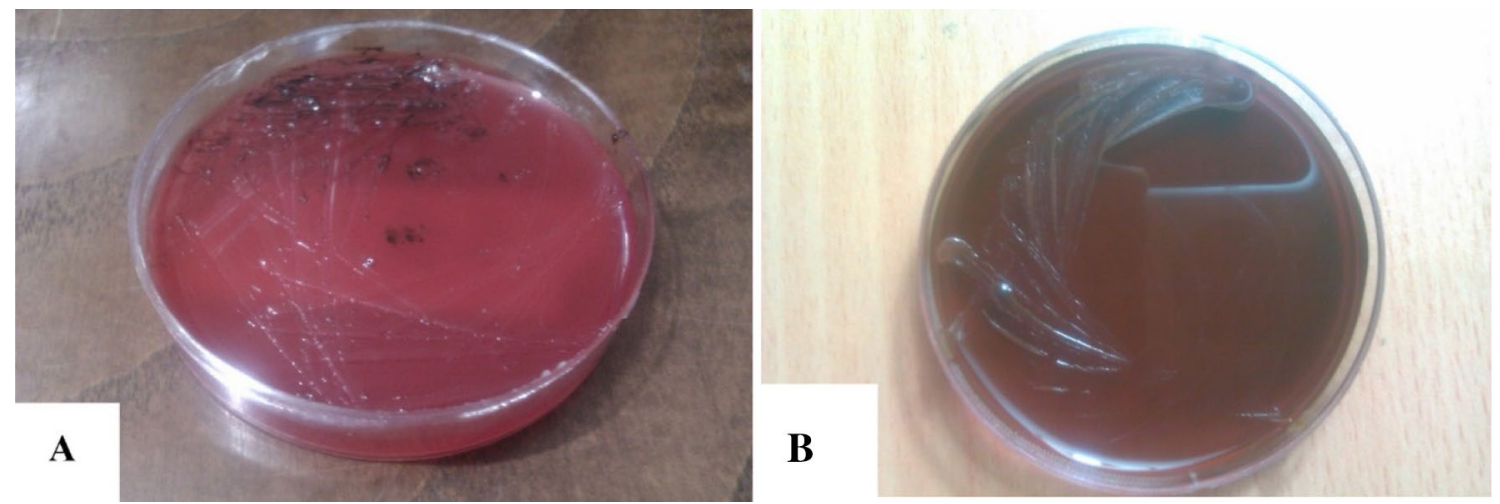

Fig. 6 Cultured lubricant in blood agar (a) and EMB (b) medium and they were kept for $48 \mathrm{~h}$ in an incubator at $35^{\circ} \mathrm{C}$ 

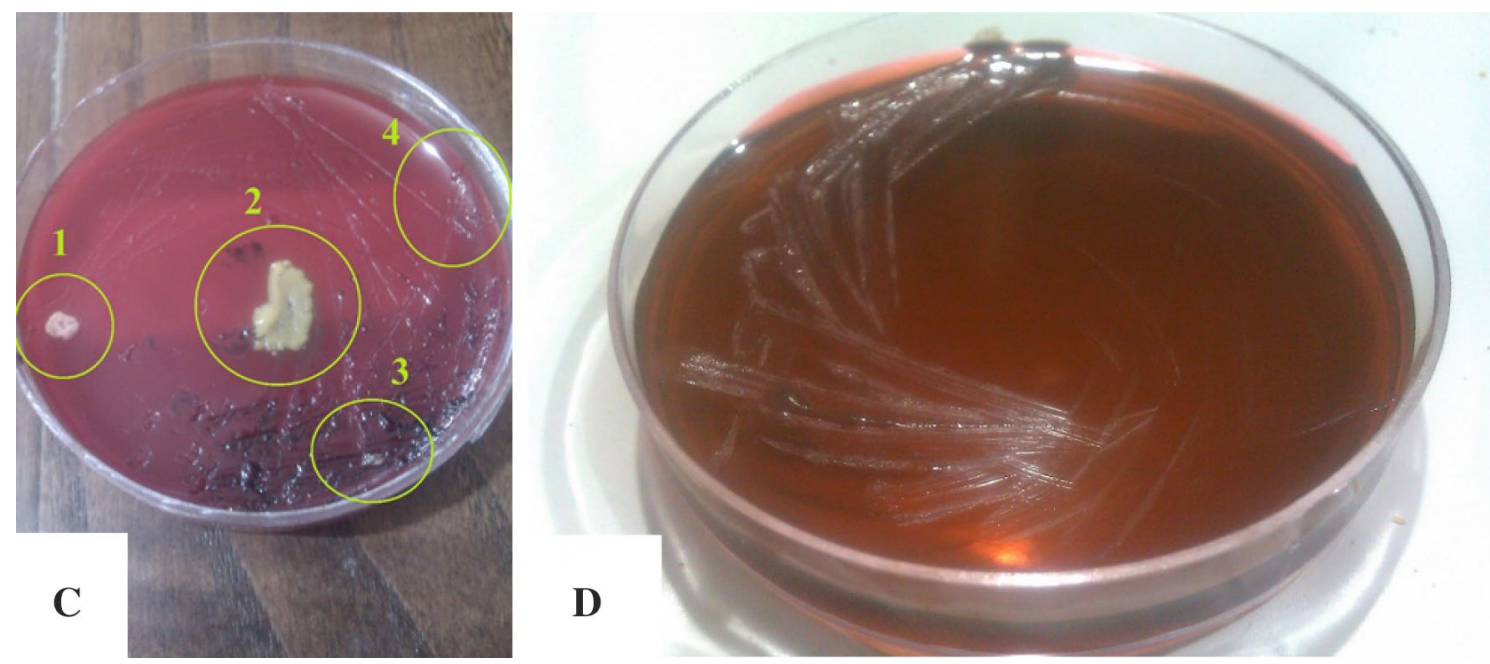

Fig. 7 Four species grew in blood agar (c) and no microorganisms grew in EMB (d) after 2 days

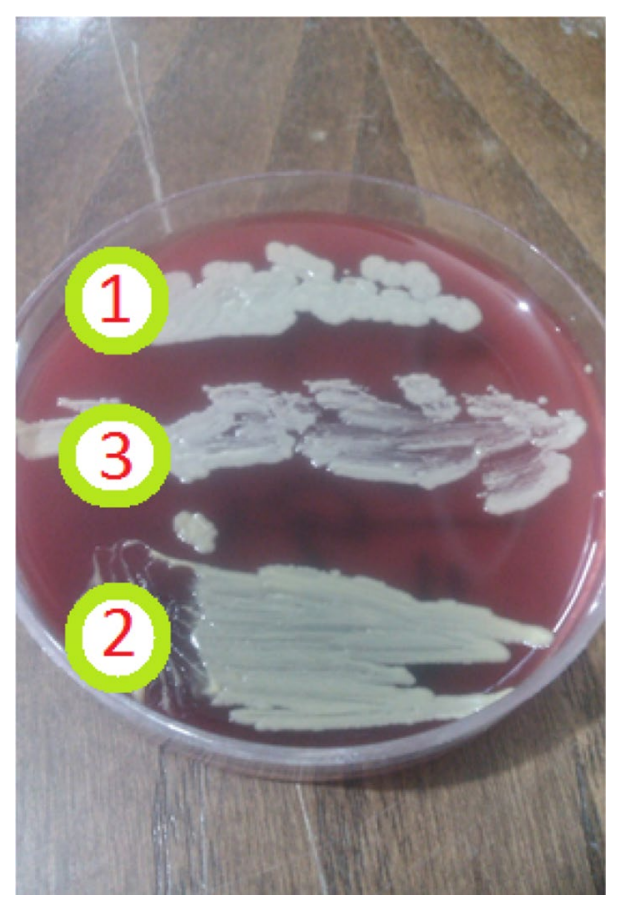

Fig. 8 Three bacteria were transferred to another blood agar medium and put in the incubator for $24 \mathrm{~h}$ at $35^{\circ} \mathrm{C}$ to check them under a microscope

in Fig. 10 to create McFarland standards. Then, 150 lambdas $(\lambda)$ of the McFarland standards were mixed with $10 \mathrm{~mL}$ lubricant and mixed using a shaker for $20 \mathrm{~min}$. Finally, the sample was kept in an incubator at $35^{\circ} \mathrm{C}$ for 10 days. After ten days, treated samples were analyzed by SARA and GC techniques.

Column chromatography was used to separate the oil components from the mud and determines the percentage of saturated, aromatic, resin, and asphaltene components during two steps before and after treatment. In this experiment, silica gel and alumina were used as fixed phase and hexane, toluene, chloroform, and ethyl acetate as mobile phase. The SARA test measured saturate, aromatic, resin, and asphaltene fractions before treatment, $12.2 \%, 15 \%, 25.6 \%$, and $47.2 \%$, respectively. Also, four fractions after treatment were measured as well and the results are 35.4\%, 15.4\%, 14.1\%, and $35.1 \%$, respectively (Table 2 ).

To evaluate the bacterial function on the lubricant samples, the saturate parts before and after the treatment are evaluated by gas chromatography. The saturate fractions were sent to the Pars Chemical Laboratory for gas chromatography analysis which is located in Tehran, Iran. Gas chromatographic analysis of the saturated hydrocarbon fractions was conducted by Thermo Corporation Instrument Model Trace GC ultra and provided with a flame ionization detector (FID). Oven temperature was programmed for 50 to $300^{\circ} \mathrm{C}$ and DB-5 capillary column of $30 \mathrm{~m} \mathrm{(30} \mathrm{m} 0.25 \mathrm{~mm}$ inner diameter $0.25 \mathrm{~lm}$ stationary phase film). The sample held $1 \mathrm{~min}$ at $50{ }^{\circ} \mathrm{C}$ and held $10 \mathrm{~min}$ at $300^{\circ} \mathrm{C}$. Samples were injected in the split-less mode with the injector temperature at $280^{\circ} \mathrm{C}$. Helium was used as carrier gas.

\section{Results}

\section{Lubricant purification}

The SARA test illustrates after treatment saturate and aromatic fractions increased, while resin and asphaltene fractions decreased (Table 2). The saturate and aromatic fraction increased $23.2 \%$ and $0.4 \%$, respectively, while the resin and asphaltene fractions decreased $11.5 \%$ and $12.1 \%$, 

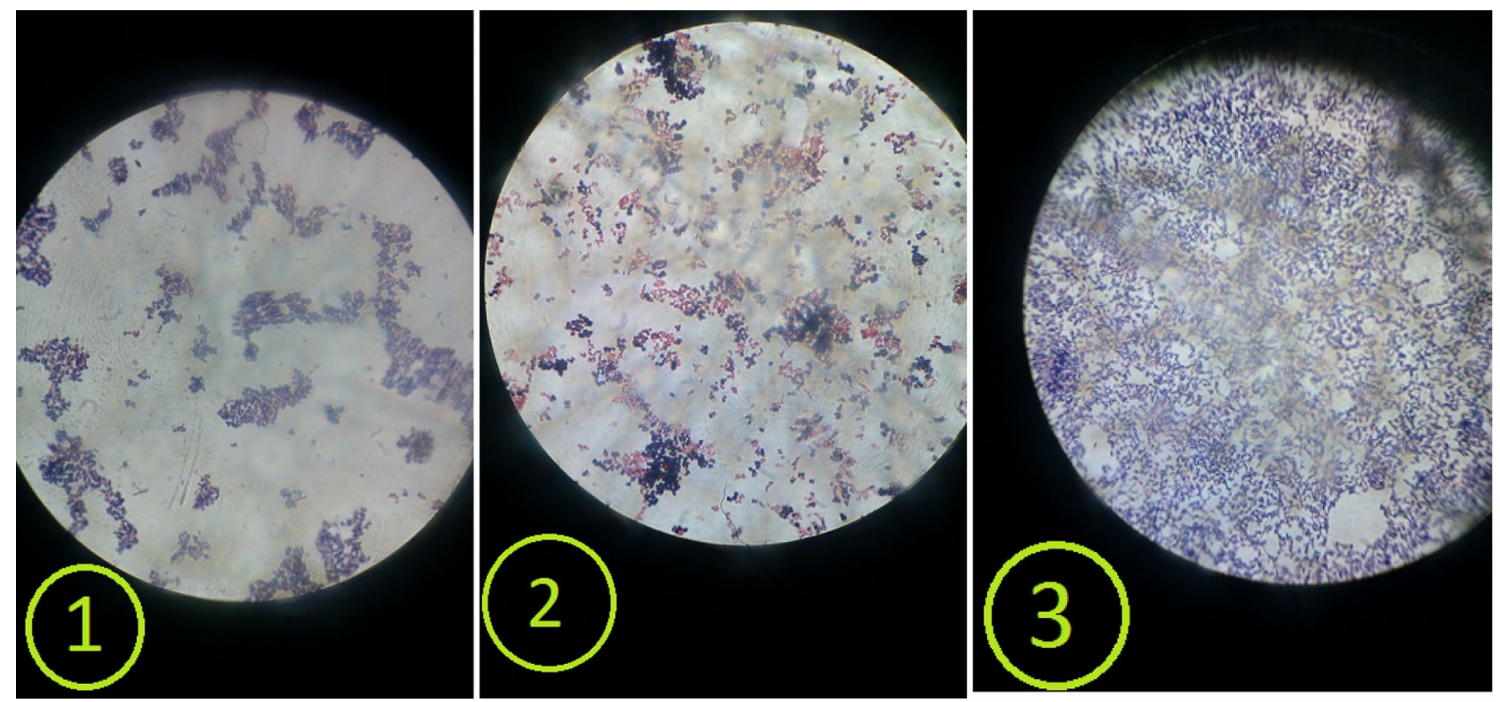

Fig. 9 After Gram's Method, three bacteria were checked under a microscope with lens number 100x. Gram's Method shows all species are gram-positive

Fig. 10 Bacteria No.2 transferred and checked again under the microscope after Gram's Method process
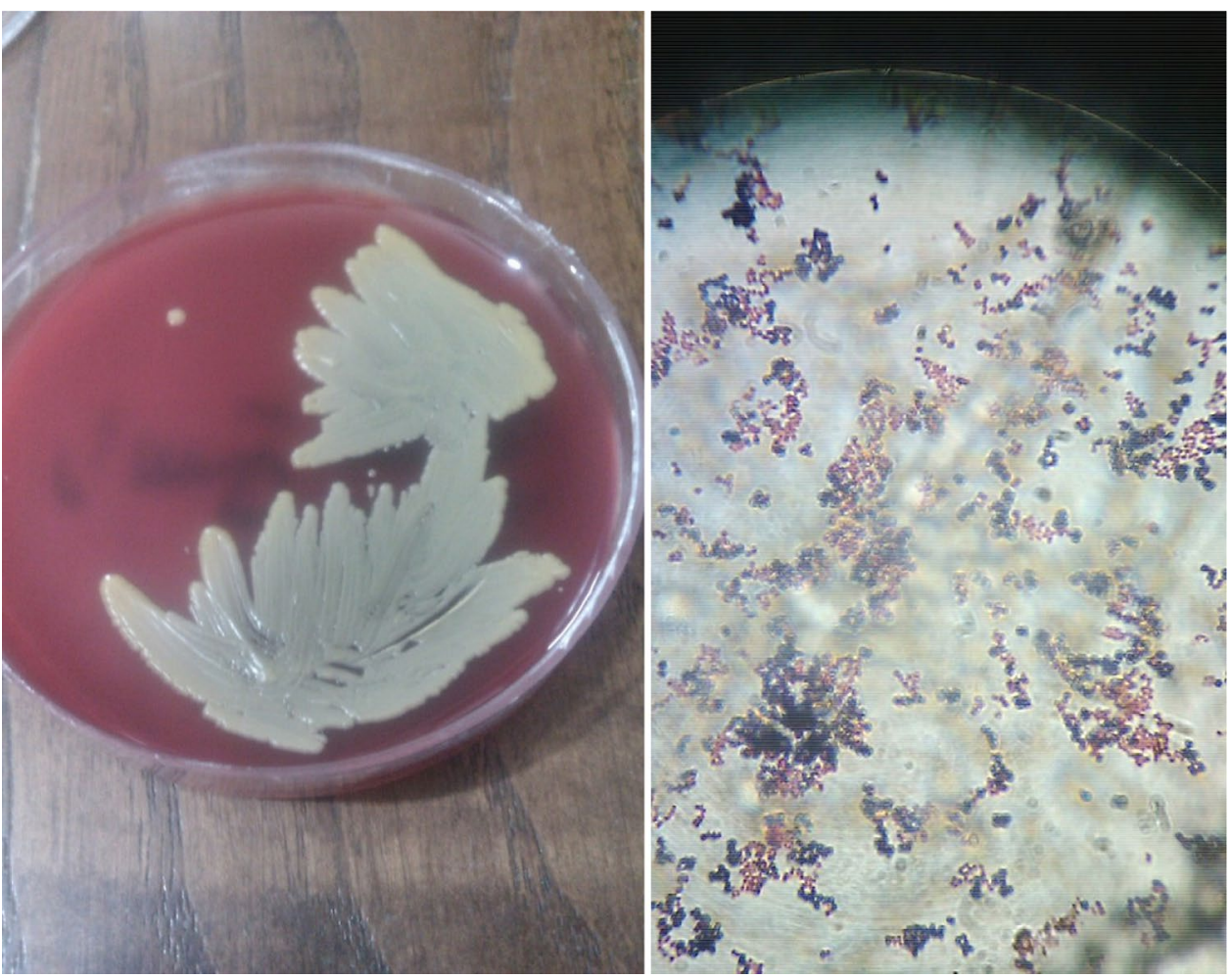

Table 2 The results of the SARA test before and after treatment

\begin{tabular}{lll}
\hline Fractions & Before treatment & After treatment \\
\hline Saturate \% & 12.2 & 35.4 \\
Aromatic \% & 15 & 15.4 \\
Resin \% & 25.6 & 14.1 \\
Asphaltene \% & 47.2 & 35.1 \\
\hline
\end{tabular}

respectively. Since saturate fraction is a good source of nutrition for bacteria, a comparison of the chromatograms obtained from the sample (before and after the treatment) can provide proper information on the bacterial functions in the lubricant sample. The spectrum obtained from the gas chromatography analysis is shown in Fig. 11. According to the previous treatment spectrum, the distribution of normal 


\section{Before treatment}

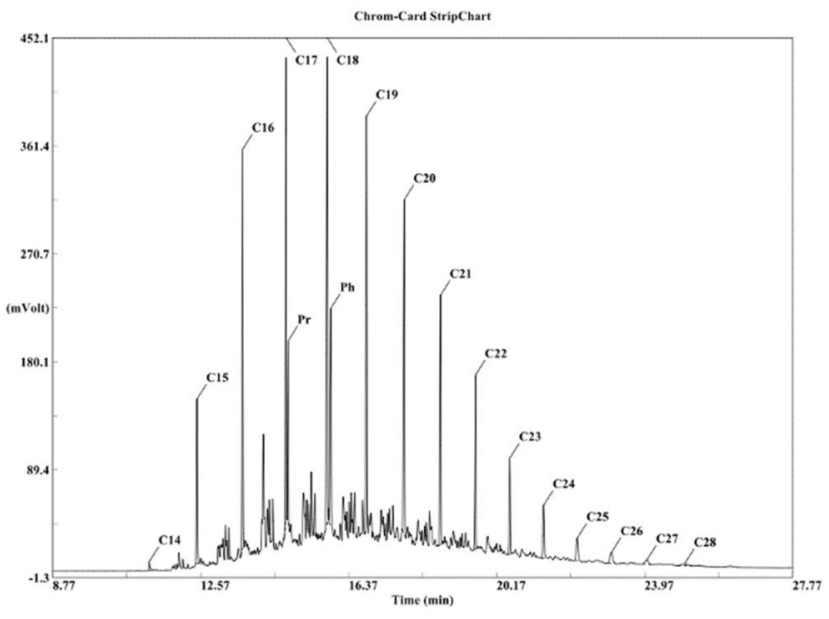

After treatment

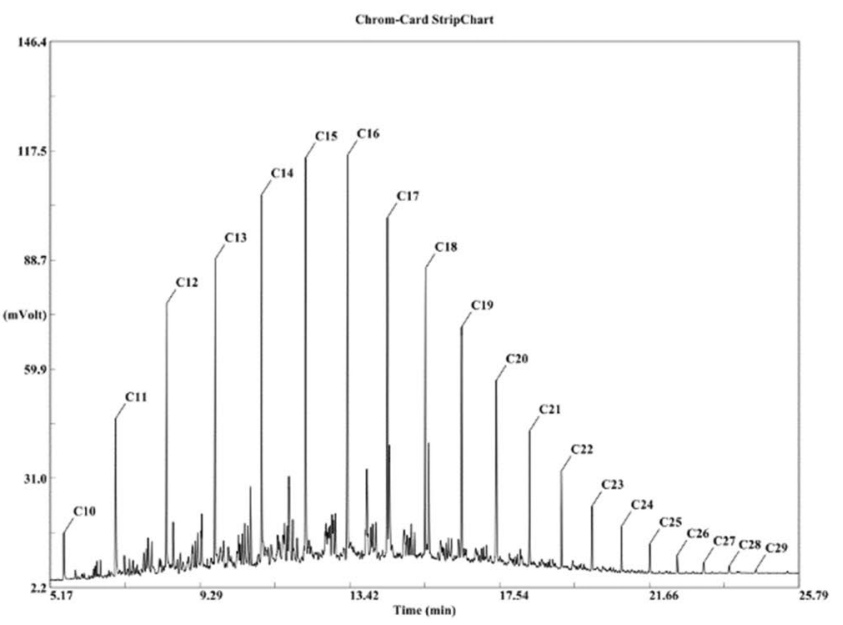

Fig. 11 GC results before and after treatment

hydrocarbon starts from $\mathrm{C}_{14}$ to $\mathrm{C}_{28}$ in the spectrum field, whereas in the new treatment spectrum we can see the $\mathrm{C}_{10}$ to $\mathrm{C}_{29}$ Components. Evidence suggests that the distribution of the normal alkane components is different from the sample before the treatment. The emergence of light hydrocarbons in the spectrum field such as $\mathrm{C}_{10}, \mathrm{C}_{11}, \mathrm{C}_{12}$, and $\mathrm{C}_{13}$ shows that the effect of bacteria on increasing the fluidity of the lubricant sample was due to breaking of the alkane chain which connected to the polar sections of the sample like as resin and asphaltene complexes. It should be noted that this process has been completed successfully over a period of three days.

\section{Discussion}

Several studies have shown various types of bacteria are able to utilize hydrocarbon as a source of energy. For instance, Deppe et al. (2005) establish that bacteria from various environments such as the arctic are able to eliminate oil residue successfully. In this study, they identified different genera: Pseudoalteromonas (two species), Pseudomonas (two species), Shewanella (two species), Marinobacter (one species), Psychrobacter (one species), and Agreia (one species). Researchers analyzed these bacteria on crude oil by GC technique, and the result shows that these bacteria utilize various hydrocarbons, such as long-chain alkanes (n-C24 to n-C34), pristane, (methyl-) naphthalenes, and xylenes, as sole carbon and energy sources (Deppe et al, 2005; Riahi et al. 2019).

Also, Osuoha et al. (2019) study identified 10 microbial from refinery wastewater that produces Tyrosinase Enzyme which can be used for Enhanced Treatment of the Organic Pollutants in Petroleum Refinery. These species include Bacillus subtilis, Verticillium sp., Penicillium sp., and Aspergillus flavus were selected and investigated on refinery wastewater. Results revealed that the immobilized enzyme significantly removed phenol and PAHs present in the wastewater by $95 \%$, and $89 \%$, respectively. These findings highlight the viability of the enzyme, tyrosinase, for the degradation of organic pollutants in petroleum-derived effluents (Justice et al. 2019).

Moreover, a study on Nigeria Delta has shown that an in situ bacteria was applied on return lubricant from an oil well for purifying soil from hydrocarbon in the (Ekanem and Ogunjobi, 2017). In this study, various types of bacteria such as Pseudomonas spp., Bacillus spp., Acinetobacter sp. and Serratia sp. demonstrated higher biodegradability for the paraffin wax. The results of the GC-FID show that for a total amount of 22,146.65 ppm (surface polluted soil), $14,087.80 \mathrm{ppm}$ (subsurface [SPSS]), and control soil (UPS) $479.67 \mathrm{ppm}$ petroleum hydrocarbons (TPH), the polycyclic aromatic hydrocarbons (PAHs) were 12,209.3 ppm for SPS, 3,248.75 ppm for SPSS and $22.72 \mathrm{ppm}$ for UPS, respectively. Total cultivable hydrocarbon which is utilized for bacterial count (TCHUB) in the case of SPS, SPSS, and UPS was $8.4 \times 10 \mathrm{cfu} / \mathrm{g}, 8.0 \times 10 \mathrm{cfu} / \mathrm{g}$, and $3.96 \times 10 \mathrm{cfu} / \mathrm{g}$, respectively.

According to the Ekanem and Ogunjobi results, three strains namely Nocardia sp., Pseudomonas sp, and Bacillus $s p$ indicate the highest potential to be used for hydrocarbon degradation. They investigate two genera Pseudomonas and Enterobacter on lubricant, and the result shows that these bacteria successfully eliminate oil residue; however, the destruction is low (Abo Taleb et al. 2019). 


\section{Concluding remarks}

The coagulase and clumping tests were used to identify the staphylococcus. The SARA and GC tests show staphylococcus can affect resin and asphaltene complexes and divide them into smaller parts which are easier for the environment to eliminate. According to the results, staphylococcus is effective to eliminate hydrocarbon in lubricating. Therefore, staphylococcus bacterium can be considered as a potentially attractive agent in eliminating the oil phase in lubricant. Not only this method reduces the costs but also avoids environmental damages of conventional methods. This study shows that by using this bacterium in the field the effect of oil pollution can be reduced on this marsh environment in a few days.

Acknowledgements This research did not receive any specific grant from funding agencies in the public, commercial, or not-for-profit sectors. The third author would like to acknowledge Research Council of the University of Tehran.

\section{Declarations}

Conflict of interest Hereby, on behalf of all the co-authors I (corresponding author) state that there is no conflict of interest for all the participating authors.

Open Access This article is licensed under a Creative Commons Attribution 4.0 International License, which permits use, sharing, adaptation, distribution and reproduction in any medium or format, as long as you give appropriate credit to the original author(s) and the source, provide a link to the Creative Commons licence, and indicate if changes were made. The images or other third party material in this article are included in the article's Creative Commons licence, unless indicated otherwise in a credit line to the material. If material is not included in the article's Creative Commons licence and your intended use is not permitted by statutory regulation or exceeds the permitted use, you will need to obtain permission directly from the copyright holder. To view a copy of this licence, visit http://creativecommons.org/licenses/by/4.0/.

\section{References}

Abo Taleb T. Al-Hameedi, Husam H. Alkinani, Shari Dunn-Norman, Nawaf A. Alashwak, Abdullah F. Alshammari, Mohammed M. Alkhamis, and Hussien W. Albazzaz. 2019 Environmental friendly drilling fluid additives: can food waste products be used as thinners and fluid loss control agents for drilling fluid? Journal SPE-195410-MS.

Abo Taleb T. Al-Hameedi, Husam H. Alkinani, Shari Dunn-Norman, Nawaf A. Alashwak, Abdullah F. Alshammari, and Mohammed M. Alkhamis. 2019 Evaluation of Environmentally Friendly Drilling Fluid Additives in Water-Based Drilling Mud. Journal SPE
Alwassiti AA, Al-Bidry MA, Mohammed K (2020) Experimental study of Zubair shale stability of east Baghdad oil field using different additives in water based mud. Journal Petrol Explor Prod Technol 10:1215-1225

Amanullah, M. 2007 Screening and Evaluation of Some EnvironmentFriendly Mud Additives to Use in Water-Based Drilling Muds. SPE E\&P Environmental and safety conference, Galveston, Texas, USA. Pp 5-7,

Bayat Z, Hassanshahian M, Askeri Hesni M (2015) Enrichment and isolation of crude oil degrading bacteria from some mussels collected from the Persian Gulf. Mar Pollut Bull 101(1):85-91

Deppe U, Richnow HH, Michaelis W, Antranikian G. 2005 Degradation of crude oil by an arctic microbial consortium. Journal NCBI.

Elshreef K, Lashin A. 2016 Investigation of mud density and weighting materials effect on drilling fluid filter cake properties and formation damage. Journal of African Earth Sciences, 117. https://doi. org/10.1016/j.jafrearsci.2016.02.003

Ekanem JO, Ogunjobi AA (2017) Hydrocarbon degradation potentials of bacteria isolated from spent lubricating oil contaminated soil. J Appl Sci Environ Manag 21(5):973-979

Fink J 2015. Petroleum Engineer's Guide to Oil Field Chemicals and Fluids. $2^{\text {th }}$ edition. Gulf Professional Publishing Chapter 1.

Folayan JA, Anawe PA, Abioye PO, Elehinafe FB Oluwabunmi 2017 Selecting the Most Appropriate Model for Rheological Characterization of Synthetic Based Drilling Mud. International Journal of Applied Engineering Research.

Gillespie S, Hawkey PM. 2006Principles and practice of clinical bacteriology, $2^{\text {th }}$ edition. wiley publications,

Hakimi far Sepehr, Rasti Arash and Riahi Mohammad Ali. 2019 Investigation of rhodococcus equi effects on crude oil from biological degradation aspects by SARA, FT-IR and GC Technique. American Journal of Petrochemistry.

Haut R., Rogers, J., McDole, B., Burnett, D., and Olatubi, O. 2007 Minimizing Waste during Drilling Operations. National Technical Conference and Exhibition, Houston, Texas. 10-12

He S, Liang L, Zeng Y, Ding Y, Lin Y, Liu X 2016 The influence of water-based drilling fluid on mechanical property of shale and the wellbore stability. Petroleum Journal.

Okoye AU, Chikere CB 2019Characterization of Potential Paraffin Wax Removing Bacteria for Sustainable Biotechnological Application. Journal SPE.

Osuoha JO, Abbey BW, Egwim EC 2019 Production and Characterization of Tyrosinase Enzyme forEnhanced Treatment of Organic Pollutants in Petroleum Refinery Effluent. SPE Nigeria Annual International Conference and Exhibition, 5-7.

Patel D, Thakar V, Pandian S, Shah M, Sircar A 2019A review on casing while drilling technology for oil and gas production with well control model and economical analysis. Journal Sciencedirect.

Vidali M 2001Bioremediation. An Overview. Pure and applied chemistry Journal. 73.

Zimbro MJ, Power DA, Miller SM, Wilson GE, Johnson JA 2009 Manual of Microbial Culture Media, $2^{\text {th }}$ edition.

Publisher's Note Springer Nature remains neutral with regard to jurisdictional claims in published maps and institutional affiliations. 